some success in related experiments with human cells. Francisco Silva is vice-president of research at PrimeGen Biotech, based in Irvine, California. He says that, working with samples from 22 testes, the company "has successfully therapeutically reprogrammed human germ cells and differentiated them to multiple cell types in vitro". Silva has presented the data at scientific meetings, and says he plans to submit results for publication soon. But Shinohara is again sceptical.

Hasenfuss, Shinohara and PrimeGen all say they have filed for international patents on their technologies. Some legal squabbles are likely. Hasenfuss, for example, claims work in adult mice is different from that in neonatal mice. Shinohara says the two experiments are essentially the same.

Whether any of the mouse-based claims would cover humans is not clear. Even if a patent office grants a patent, it may be invalidated by the courts, says Lynn Pasahow, an intellectual-property attorney with Fenwick \& West in Mountain View, California (see 'US to rule on research patent'). "It may be difficult to know the scope of the valid claims," he says.

In any case, researchers still have to show that the cells can be derived, grown and manipulated just like those from the alternative source, cloned embryos. In theory, the reprogrammable testes cells could circumvent the ethical difficulties of stemcell work that involves destroying human embryos. "This could put the embryonic stem-cell people out of business," says Peter Donovan, a stem-cell expert at the University ofCalifornia, Irvine. "But it remains to be seen whether they work in humans." David Cyranoski

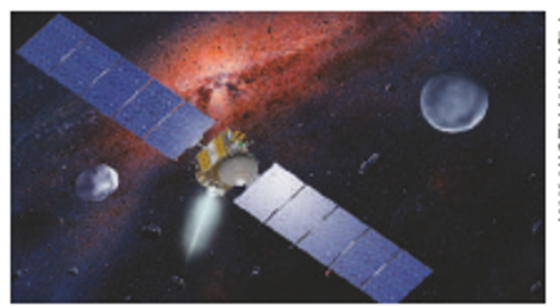

NASA's Dawn asteroidmission has been revived.

astrobiologists at the meeting applauded the news, but vowed to keep lobbying for more money. "We can see this as the beginning of a negotiation," says Baruch Blumberg, a Nobel laureate and former director of the NASA Astrobiology Institute.

Tomy Reichhardt

\title{
US to rule on research patent
}

\section{WASHINGTON DC}

It is a case that questions the very nature of what can be patented. Before the US Supreme Court adjourns at the end of June, it may decide whether a patent based on a biological relationship between two substances can be issued. A verdict could have implications for many other US and worldwide patents.

"The United States is often an incubator for these issues," says Francis Gurry, deputy director-general of the World Intellectual Property Organization in Geneva, Switzerland. "The world is watching with a great deal of interest."

A natural phenomenon or a law of nature generally cannot be patented, but a process that takes advantage of that phenomenon or law can be. Lawyers have been battling over this rule in biotechnology cases since at least 1980 , when the Supreme Court ruled that a newly discovered microbe capable of digesting petrol could be patented. That case opened the door for the biotechnology industry and ushered in patents for antibodies, microorganisms and cells.

Some feel that it is now too easy to patent natural phenomena. "There might be some individuals who would like to close that door," says Nick Godici, a former US Patent and Trademark Office commissioner .

The latest case Laboratory Corporation of America Holdings (LabCorp) against Metabolite Laboratories deals with the field of biomedical diagnostics. It stems from a patentinfringement case over

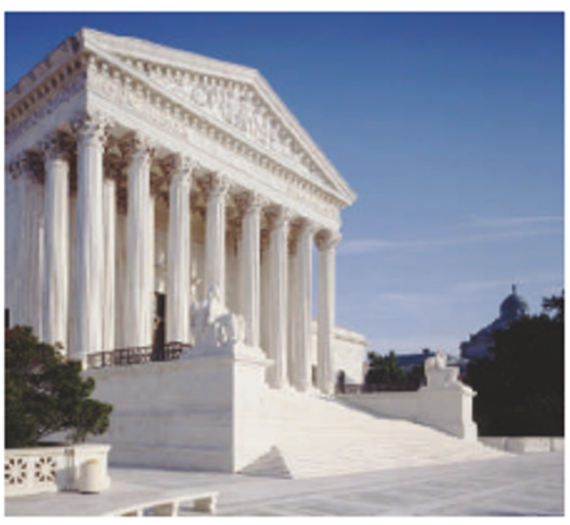

Thought police: the Supreme Courtis reviewing a case that could "wreak havoc on the patent world".

a method for diagnosing vitamin B deficiencies. In 1990 , Metabolite patented a diagnostic test, based on an assay that measures blood levels of homocysteine, an amino acid. High levels of homocysteine are correlated with low levels of vitamin $B_{12}$. Physicians often order such tests because high homocysteine levels are also correlated with increased health risks such as heart attacks, stroke and birth defects.

Metabolite licensed the test to LabCorp, a clinical testing company. LabCorp stopped using it in 1998 and replaced it with a similar test developed by another company. When LabCorp stopped paying royalties, Metabolite sued for patent infringement. LabCorp lost, was ordered to pay $\$ 7.8$ million, and lost again on appeal.

In the case heard by the Supreme Court on 21 March, LabCorp argued that Metabolite had patented a law of nature by asserting ownership of the relationship between homocysteine levels and vitamin $B_{12}$. Under these circumstances, LabCorp said, physicians infringe the patent simply by thinking about the relationship when studying test results.
Miguel Estrada, an attorney for Metabolite, told the court that the natural relationship is integral to the diagnostic step. Addressing the broader issue, he argued, could "wreak havoc on the patent world".

A corresponding European patent does not daim to cover the relationship between levels of homocysteine and vitamin $B_{12}$, and is not currently being challenged, says Siobhan Yeats, a biotechnology director at the European Patent Office in Munich, Germany.

The Supreme Court could now come to a verdict, pass the case back to thelower courts, or dismiss it altogether. One complication is that the biological-relationship argument was not addressed in the lower courts.

And although no one can predict which way the vote will go, at least one justice indicated his thoughts during the hearing. Justice Stephen Breyer hinted that patenting a scientific phenomenon might limit researchers' motivations to search for new cures. "If you don't provide them with an incentive," he said, "they may think of less." Jacqueline Ruttimann 